period he designed the apparatus described in his well-known paper on "A Study of the Vertical Gradient of Temperature in the Atmosphere near the Ground" (London Met. Office, Geoph. Memoirs, No. $46,1929)$. This work yielded much valuable informa. tion on the thermal structure of the lower layers of the atmosphere, and has formed the basis of similar work carried out afterwards in other parts of the world. In 1929, Mr. Johnson became Director of Experiments at the Porton Experimental Station, under the War Office, and was promoted later to his present post of Chief Superintendent, Chemical Defence Research Department.

\section{George William Hill (r838-r9r4)}

ON March 3 occurs the centenary of the birth of the American astronomer, George William Hill, who, said Simon Newcomb, "will easily rank as the greatest master of mathematical astronomy during the last quarter of the nineteenth century". His father had emigrated to the United States in 1808 and Hill was born in New York, but his boyhood was passed in the country at West Nyack, N.Y., and there on his little farm he passed away on April 16, 1914, having received some of the highest honours science could bestow. Entering Rutgers College, New Jersey, at the age of seventeen years, he graduated in 1859 and then proceeded to Cambridge, Mass. Early in 1861 he was offered a post under Runkle, the superintendent of the American "Nautical Almanac", and he remained connected with the "Almanac" Office for more than thirty years. In 1877-78, there appeared his new method of dealing with the moon's motion, "his most original contribution to our knowledge of celestial mechanics", and about the same time under Newcomb he took up problems connected with Jupiter and Saturn, and at which he laboured for fifteen years. After the completion of this work he retired from the "Almanac" Office and settled again at West Nyack. . "It is difficult," said one writer, "to find such another man as Hill in the whole history of Science. Although holding only a humble post in the 'Nautical Almanac' Office, he lived happily in the liberty it afforded him, and never sought to improve his material position. All he asked for was peace and freedom to prosecute his work". He received the Gold Medal of the Royal Astronomical Society in 1887 and the Copley Medal of the Royal Society in 1909, and France elected him a corresponding member of its Institute. His first paper was published in Runkle's Mathematical Monthly, just when he had graduated, and his last in the Astronomical Journal in January 1914, three months before he died.

\section{Jacob Da Silva Solis-Cohen (1838-1927)}

Dr. JACob DA Silva Solis-CoHen, the founder of laryngology in the United States, was born in New York City on February 28, 1838, of distinguished Spanish and Portuguese ancestry. He received his medical education at Jefferson Medical College and the University of Pennsylvania where he qualified in 1860. After serving for a short time in the United States Army and Navy during the Civil War, he devoted himself to the study of laryngology. His first work on the subject, entitled "Inhalation in the Treatment of Disease", was published in 1867, and was followed in 1872 by his great work "Diseases of the Throat and Nasal Passages", which at once became a standard text-book and ranked with those of Morell Mackenzie (1860) and Francke F. Bosworth (1881) among the classics of laryngology. In 1874, appeared Solis-Cohen's monograph on "Croup in its Relations to Tracheotomy", based on the study of 5,000 recorded cases; in 1875 he published a book on "The Throat and Voice". In 1866, he was the first in the United States to institute regular lectures on laryngology at the Philadelphia School of Anatomy. In 1870 he was appointed lecturer on laryngoscopy and diseases of the throat and chest in the Jefferson Medical College and two years later professor of laryngology. He was one of the founders of the Archives of Laryngology and for many years edited the laryngological department of the American Journal of the Medical Sciences. He also helped to found the American Laryngological Association, of which he was the second president in 1880-82. As the result of his experience in the Civil War he excelled in the surgery of the upper air passages. In 1892 he was the first in America to perform a successful complete laryngectomy. His death occurred on December 22, 1927.

\section{The Soviet Arctic Enterprise}

Trre final stages in the rescue of $M$. Papanin and his three comrades began on February 16, when two planes from the Murman and Taimyr respectively landed on the drifting floe. It was decided, however, not to remove the men by air since they were in no immediate danger. During the next two days the Taimyr, guided by an aeroplane, fought her way through the pack-ice to the vicinity of the camp and on February 18, the four men Papanin, Krenkel, Shirshov and Federov, with all their records and equipment, were taken on board the ice-breakers. The drift had lasted for $\mathbf{2 5 8}$ days and covered about twelve hundred miles. The relief ships Taimyr and Murman, on emerging from the pack, set out for the port of Murmansk in northern Russia. Congratula. tions are to be extended to these four men of science and to their rescuers. It is expected that much of scientific importance will accrue from the data obtained at such great risk (see also p. 344 of this issue), and we look forward to the publication of the results when they have been finally worked out.

\section{Pithecanthropus and Peking Man}

Prof. F. Weidenreich, commenting in another column of this issue of NATURE (see p. 378) on the recent discovery in Java of another skull and a fragment of jaw of Pithecanthropus, sets out the grounds for regarding the new evidence, not only as bringing a prolonged controversy to a sudden close, but also as confirming conclusively the close relation between Pithecanthropus and Peking man, which he had inferred from his study of the material previously known. From the time of the discovery by Dr. 